\title{
INFLUENCE OF SCARIFICATION AND GIBBERELLIC ACID ON SEED DORMANCY AND GERMINATION OF POMEGRANATE SEEDLINGS
}

\section{INFLUENCIA DE LA ESCARIFICACIÓN Y EL ÁCIDO GIBERÉLICO EN LA DORMANCIA Y GERMINACIÓN DE SEMILLAS DE GRANADA}
${ }^{1}$ Laís Naiara Honorato Monteiro, ${ }^{2}$ Antonio Flavio Arruda Ferreira, ${ }^{3}$ Glaucia Amorim Faria, 4 Maria Gabriela Fontanetti Rodrigues, ${ }^{5}$ Aparecida Conceição Boliani

\author{
1,3,4 y 5 State University of São Paulo \\ 2 Mato Grosso State University \\ ${ }^{1}$ laismonteiiro@gmail.com, ${ }^{2}$ arrudaferreira.af@gmail.com, ${ }^{3}$ glaucia.a.faria@unesp.br, \\ ${ }^{4}$ maria.gf.rodrigues@unesp.br, ${ }^{5}$ aparecida.boliani@unesp.br
}

Citación: Monteiro, L., Ferreira, A., Faria, G., Rodrigues, M., and Boliani, A. (2021). Influence of scarification and gibberellic acid on seed dormancy and germination of pomegranate seedlings. Revista de Investigación Agraria y Ambiental, 12(2), 25 - 37. DOI: https://doi.org/10.22490/21456453.3852

\begin{abstract}
Contextualization: Due to the importance of pomegranate among fruit species, studies on the physiology of its seeds and the production of seedlings are essential for the expansion of commercial orchards.
\end{abstract}

Knowledge gap: With the portrayed importance of this crop and its use in various sectors, such as agro-industrial and pharmaceutical products, the development of continuous and straightforward propagation techniques that provide a uniform seedling development will provide favorable conditions for the cultivation and exploitation of the species, improving its use and boosting new research.
Purpose: To evaluate the effect of scarification and immersion in gibberellic acid on the dormancy of pomegranate seeds, aiming at accelerating the emergence and improving the initial growth of seedlings.

Methodology: The sarcotesta was removed and the seeds were scarified. The treatments consisted of a scarified control, a non-scarified control (seeds with and without scarification), and seeds subjected to the concentrations of $500 \mathrm{mg} \mathrm{L}^{-1}, 1,000 \mathrm{mg} \mathrm{L}^{-1}$, and $1,500 \mathrm{mg} \mathrm{L}^{-1}$ of $\mathrm{GA}_{3}$. The following variables were evaluated: initial emergence, emergence percentage, mean emergence time, leaf number, stem diameter, shoot length, root length, and total dry matter. 
Results and conclusions: The pomegranate $\mathrm{cv}$. Valencian seeds do not have tegument-related dormancy. In order to favor the emergence percentage and the initial growth of pomegranate seedlings, mechanical scarification and immersion of the seeds in $\mathrm{GA}_{3}$ are dispensed. Scarification and immersion of pomegranate seeds in $500 \mathrm{mg} \mathrm{L}^{-1}$ of $\mathrm{GA}_{3}$ are recommended to produce seedlings in a shorter time.

Keywords: Cultivar Valenciana; Emergence; Gibberellin; Punica granatum; Sarcotesta

\section{RESUMEN}

Contextualización: debido a la importancia de la granada en los árboles frutales, los estudios sobre la fisiología de las semillas y la producción de plántulas son esenciales para la expansión de los huertos comerciales.

Vacío de conocimiento: considerando la importancia de este cultivo y su uso en diversos sectores, como el agroindustrial y el farmacéutico, el uso de técnicas de propagación simples y continuas que permiten un desarrollo uniforme de las plántulas proporcionará las condiciones favorables para el cultivo y la explotación de la especie, mejorar su uso e impulsar nuevas investigaciones.
Propósito del estudio: evaluar el efecto de la escarificación y la inmersión en ácido giberélico en la fase de latencia de las semillas de granada, a fin de acelerar la aparición y mejorar el crecimiento inicial de las plántulas.

Metodología: se retiró la sarcotesta y se escarificaron las semillas. Los tratamientos consistieron en testigo y control (semillas con y sin escarificación) y concentraciones, $500 \mathrm{mg}$ $\mathrm{L}^{-1}, 1000 \mathrm{mg} \mathrm{L}^{-1}$ y $1500 \mathrm{mg} \mathrm{L}{ }^{-1}$ de $\mathrm{GA}_{3}$. Se evaluaron las siguientes variables: la emergencia inicial, el porcentaje de emergencia, el tiempo medio de emergencia, el número de hojas, el diámetro del tallo, la longitud del brote, la longitud de la raíz y la materia seca total.

Resultados y conclusiones: las semillas de granada cv. valenciana no tienen dormancia relacionada con el tegumento. Para favorecer el porcentaje de emergencia y el crecimiento inicial de las plántulas de granada, se prescinde de la escarificación mecánica y de la inmersión de las semillas en $\mathrm{GA}_{3}$. Se recomienda la escarificación y la inmersión de las semillas de granada en $500 \mathrm{mg} \mathrm{L}^{-1}$ de $\mathrm{GA}_{3}$ para obtener las plántulas en menos tiempo.

Palabras clave: Cultivar Valenciana; Emergencia; Giberelina; Punica granatum; Sarcotesta 


\section{GRAPHIC SUMMARY}

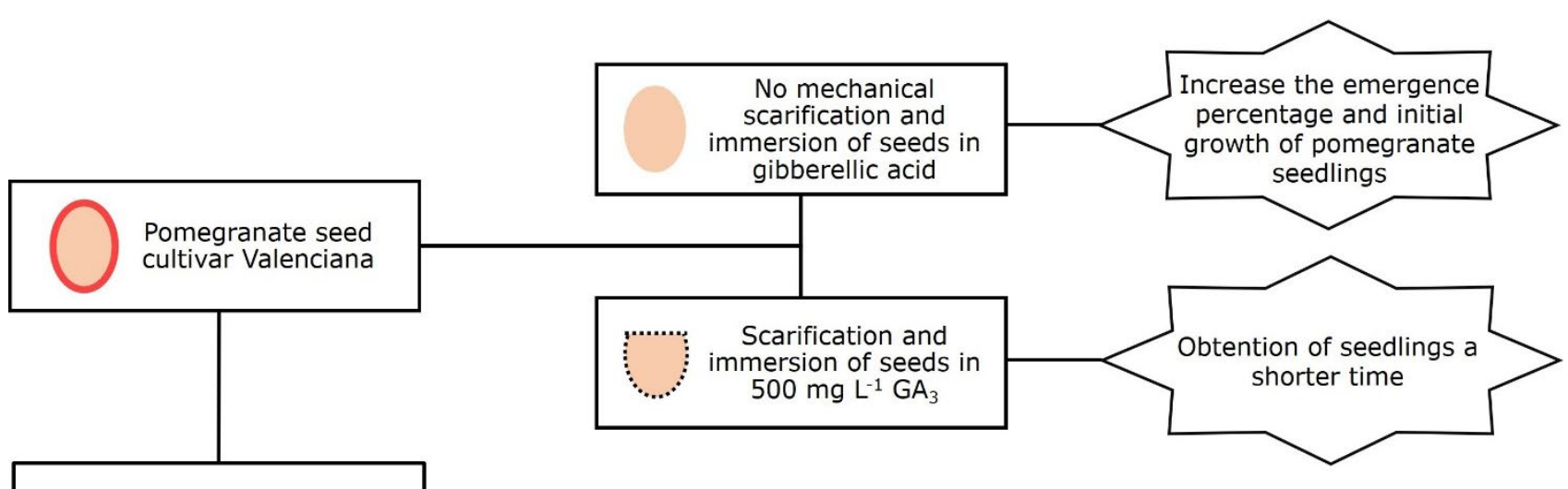

Do not have tegument-related dormancy.

Source: authors

\section{INTRODUCTION}

Due to the several functional and nutraceutical properties found in the plant, the pomegranate (Punica granatum) has gained prominence in the market of fresh fruits, in industry, and in studies regarding its constituents (Asadi et al., 2018).

Among the main substances of these fruits, the phenolic compounds, tannins, flavonoids, and alkaloids are often highlighted (Peixoto et al., 2014). Furthermore, throughout the last decade, studies suggest that this fruit presents antimicrobial properties and high antioxidant power, with the potential for use in the treatment and prevention of cancer, diabetes, and cardiovascular and degenerative diseases (Bensaad et al., 2017).

These important nutraceutical characteristics of the pomegranate make it an excellent alternative for cultivation as consumers increasingly demand foods with organoleptic quality and good nutritional composition. For this, first, it is necessary to understand the appropriate propagation techniques, involving the physiological aspects of the seeds, such as dormancy, in order to make the sector promising.

Seedling production is the first stage of the installation of productive orchards. In this context, seeds are of utter importance for the success of agricultural crops since they are designed to produce seedlings to be used as rootstocks. For pomegranate, the use of rootstocks is a reality in the sector, ensuring the production of vigorous genotypes that provide high planting density and reduced fruiting time, using materials with desirable agronomic traits, such as drought tolerance and resistance to pests and diseases, which can be evaluated during development and behavior studies (ValizadehKaji et al., 2020).

Given its importance, the production of pomegranate rootstocks demands great knowledge regarding seed germination and seedling emergence (Batista et al., 2011); however, there are still reports of complications in the literature regarding the obtainment of high 
emergence values (Materechera \& Seeiso, 2013), leading to the assumption that pomegranate seeds present dormancy.

According to Khadivi-Khub et al. (2015) and Aguilera-Arango et al. (2020), pomegranate seeds present varied physical dormancy levels in the tegument according to the cultivar, with this behavior greatly influencing cultivation and the production of commercial orchards. In adverse situations related to germinative and emergence processes due to possible seed dormancy, Taiz et al. (2017) recommended the use of pre-germinative treatments, such as scarification of the seed coat and seed immersion with plant growth regulators, such as gibberellic acid, and verified that the association of these techniques could intensify the emergence rate and improve plant uniformity (Vasconcelos et al., 2015).

In this perspective, this study aims to evaluate the effect of mechanical scarification and immersion in gibberellic acid on the dormancy of pomegranate seeds, aiming at accelerating germination and the initial seedling growth.

\section{MATERIALS AND METHODS}

The experiment was performed at the Phytotechny Laboratory of the Department of Phytotechny, Food Technology, and Socioeconomics of the Faculty of Engineering, UNESP, Ilha Solteira, from August to October 2015. The physiologically mature fruits collected from adult 10-year-old plants of the pomegranate cultivar 'Valenciana' were obtained from a commercial producer in the municipality of Presidente Prudente $\left(22^{\circ} 3^{\prime} 21.24^{\prime \prime}\right.$ S latitude, 5121'35.16" W longitude, and $477.6 \mathrm{~m}$ of elevation).

The fruits had their pulp removed, and the seeds were homogenized. Afterward, the sarcotesta was removed by pressing the seeds through a $2 \mathrm{~mm}$ mesh sieve under running water (Melo \& Seleguini, 2013), and the material was dried in the shade on absorbing paper sheets for 12 hours. The seeds were divided into two lots, one formed by non-scarified seeds (WITHOUT) (Figure 1A) and another (WITH) formed by seeds scarified with a sandpaper sheet no 100 in the region opposite to that of radicle emergence (Figure 1B).

The seeds were soaked for four hours in a gibberellic acid solution (Dinâmica ${ }^{\circledR}$ ) without aeration. Aiming at overestimating the doses used by Takata et al. (2014), the purpose of this study was to verify whether gibberellic acid, at high doses, could improve the emergence conditions of pomegranate seedlings. For this, considering the medium concentration of $1,000 \mathrm{mg} \mathrm{L}^{-1}$, the following treatments were defined: scarified control (seeds with scarification), non-scarified control (seeds without scarification), and three concentrations: low (500 $\left.\mathrm{mg} \mathrm{L}^{-1} \mathrm{GA}_{3}\right)$, medium $\left(1,000 \mathrm{mg} \mathrm{L}^{-1} \mathrm{GA}_{3}\right)$, and high $\left(1,500 \mathrm{mg} \mathrm{L}^{-1} \mathrm{GA}_{3}\right)$. In all treatments, the seeds were soaked in $\mathrm{GA}_{3}$ for four hours. For the control treatment, the seeds were soaked only in deionized water for the same period.

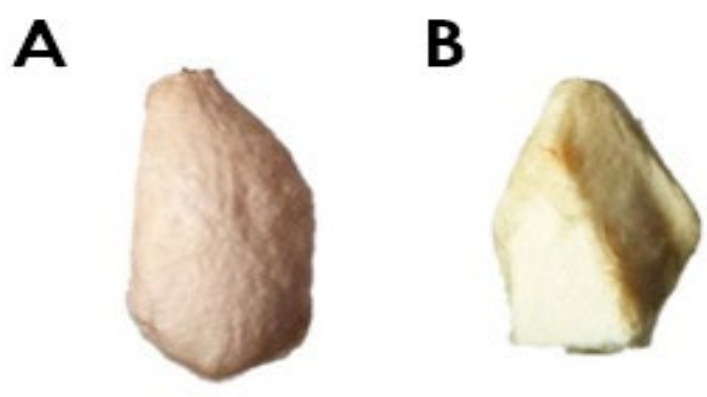

Figure 1. Pomegranate seeds (Punica granatum) without (A) and with (B) scarification. 0.7x magnification.

Source: Authors.

The experimental design was completely randomized, in a $2 \times 3$ factorial arrangement (scarification $\times$ concentrations of gibberellic acid) with four replications, each formed by 100 seeds. 
After immersion, the seeds were sown in expanded polystyrene trays with 200 cells filled with a commercial organic substrate (Bioplant $\left.{ }^{\circledR}\right)$, which were installed in a plant nursery equipped with a fan and pad evaporative cooling system $\left(28 \pm 2{ }^{\circ} \mathrm{C}\right)$ and controlled irrigation twice a day, for 3 minutes $\left(1,800 \mathrm{~cm}^{3} \mathrm{~min}^{-1}\right)$. The Bioplant ${ }^{\circledR}$ substrate presented a $0.44 \mathrm{~g}$ $\mathrm{cm}^{-3}$ density, with $28.30 \%$ of compostable organic matter, $15.72 \%$ of organic carbon, and a $54 / 1$ ratio of organic carbon and total nitrogen.

The following variables were daily evaluated until the stabilization of emergence: initial emergence, emergence percentage, and mean emergence time (Labouriau, 1983). At 50 days after sowing, the following variables were evaluated: number of leaves, stem diameter $(\mathrm{mm})$, root length $(\mathrm{cm})$, shoot length $(\mathrm{cm})$, and total dry matter (mg). For the total dry matter, the seedlings were placed in paper envelopes and taken to a forced-air circulation oven at $65^{\circ} \mathrm{C}$, where they remained until reaching constant weight (72 hours).
The treatment means were compared by Dunnett's test using the scarified control and non-scarified control means (5\%) through the statistical software ACTION STAT 3.7.

The data were analyzed using the software SISVAR (Ferreira, 2019). The assumption of normality was tested by the Shapiro-Wilk test, using the F-test in the analysis of variance to compare the means when a significant difference was found for the factors with two levels (with and without scarification). Tukey's test was used to compare the means of the treatments for the factors with three levels (low, medium, and high concentrations) when a significant difference was found for each variable. All statistical tests were performed at a $5 \%$ level of probability.

\section{RESULTS AND DISCUSSION}

Table 1 shows the comparisons of the means of the scarified control (seeds with scarification) and non-scarified control treatments (seeds without scarification).

Table 1. Mean initial emergence (IE), emergence percentage (EP), mean emergence time (MET), number of leaves (NL), stem diameter (SD), shoot length (SL), root length (RL), and total dry matter (TDM) of pomegranate seedlings (Punica granatum) produced from seeds subjected to scarification and $\mathrm{GA}_{3}$ concentrations (mg $\mathrm{L}^{-1}$ ).

\begin{tabular}{|c|c|c|c|c|c|c|c|c|}
\hline TREATMENTS & $\begin{array}{c}\text { IE } \\
\text { (days) }\end{array}$ & $\begin{array}{c}\text { EP } \\
(\%)\end{array}$ & $\begin{array}{c}\text { MET } \\
\text { (days-1) }\end{array}$ & NL & $\begin{array}{c}\text { SD } \\
(\mathrm{mm})\end{array}$ & $\begin{array}{c}\text { SL } \\
(\mathbf{c m})\end{array}$ & $\begin{array}{c}\text { RL } \\
(\mathrm{cm})\end{array}$ & $\begin{array}{l}\text { TDM } \\
\text { (mg) }\end{array}$ \\
\hline $\mathrm{WH}+0$ & 10.50 & 36.00 & 18.56 & 8.37 & 0.53 & 3.45 & 7.53 & 75.60 \\
\hline$W T+0$ & $12.50^{\mathrm{ns}}$ & $57.00^{\mathrm{ns}}$ & $22.54^{\mathrm{ns}}$ & $10.90^{*}$ & $0.62^{*}$ & $4.38^{\mathrm{ns}}$ & $8.89^{\text {ns }}$ & $93.60^{\mathrm{ns}}$ \\
\hline$W H+500$ & $7.00^{\mathrm{ns}(*)}$ & $38.00^{\text {ns(ns) }}$ & $15.77^{\mathrm{ns}(*)}$ & $6.55^{*(*)}$ & $0.14^{*(*)}$ & $3.13^{\mathrm{ns}(*)}$ & $6.42^{\mathrm{ns}(*)}$ & $62.73^{\mathrm{ns}(*)}$ \\
\hline$W H+1,000$ & $12.00^{\mathrm{ns}(\mathrm{ns})}$ & $41.00^{\mathrm{ns}(\mathrm{ns})}$ & $23.44^{\mathrm{ns}(\mathrm{ns})}$ & $6.80^{\mathrm{ns}(*)}$ & $0.26^{*(*)}$ & $3.41^{\mathrm{ns}(*)}$ & $8.14^{\mathrm{ns}(\mathrm{ns})}$ & $77.12^{\mathrm{ns}(\mathrm{ns})}$ \\
\hline$W H+1,500$ & $10.00^{\mathrm{ns}(\mathrm{ns})}$ & $42.00^{\mathrm{ns}(\mathrm{ns})}$ & $15.39^{\mathrm{ns}(*)}$ & $7.40^{\mathrm{ns}(*)}$ & $0.24^{*(*)}$ & $3.97^{\mathrm{ns}(\mathrm{ns})}$ & $6.89^{\mathrm{ns}(*)}$ & $73.66^{\mathrm{ns}(*)}$ \\
\hline$W T+500$ & $15.00^{*(\mathrm{~ns})}$ & $71.00^{*(\mathrm{~ns})}$ & $24.50^{*(n s)}$ & $8.05^{\mathrm{ns}(*)}$ & $0.31^{*(*)}$ & $3.42^{\mathrm{ns}(*)}$ & $10.49^{*(n s)}$ & $90.42^{\mathrm{ns}(\mathrm{ns})}$ \\
\hline$W T+1,000$ & $13.25^{\mathrm{ns}(\mathrm{ns})}$ & $66.00^{*(\mathrm{~ns})}$ & $25.23^{*(n s)}$ & $7.20^{\mathrm{ns}(*)}$ & $0.21^{*(*)}$ & $3.35^{\mathrm{ns}(*)}$ & $8.48^{\mathrm{ns}(\mathrm{ns})}$ & $86.13^{\text {ns(ns) }}$ \\
\hline$W T+1,500$ & $14.75^{*(\mathrm{~ns})}$ & $73.00^{*(\mathrm{~ns})}$ & $24.96^{*(n s)}$ & $7.40^{\mathrm{ns}(*)}$ & $0.24^{*(*)}$ & $3.56^{\mathrm{ns}(*)}$ & $7.42^{\mathrm{ns}(\mathrm{ns})}$ & $82.51^{\mathrm{ns}(\mathrm{ns})}$ \\
\hline
\end{tabular}

*Significant, nsNot significant by Dunnett test (5\% probability). Significance outside parentheses: means related to seeds with scarification (WH); Significance within parentheses: means related to seeds without scarification (WT).

Source: Authors. 
When observing the initial emergence, it is seen that, compared to the scarified control $(\mathrm{WH}+0)$, the treatments with non-scarified seeds subjected to low and high concentrations of $\mathrm{GA}_{3}(500$ and $1,500 \mathrm{mg} \mathrm{L}^{-1}$, respectively) significantly delayed in a few days the beginning of emergence (Table 1). However, compared to the nonscarified control (WT+0), only the treatment with scarified pomegranate seeds subjected to the low concentration of gibberellic acid (500 $\mathrm{mg} \mathrm{L}^{-1}$ ) showed a significant difference, emerging in a shorter time, resulting in 12.50 and 7.00 days, respectively. The variable of initial emergence becomes of utter importance, since it allows knowing the seeds behavior regarding the emergence time in the soil, optimizing the cultivation planning of this crop.

It is noted that when the pomegranate seeds without scarification were associated with the tested concentrations of gibberellic acid, the emergence percentage was statistically higher than in the scarified control $(\mathrm{WH}+0)$, with $36 \%$. However, these treatments did not differ from the non-scarified control treatment (WT+0), which showed a $57 \%$ emergence rate (Table 1). Therefore, it is seen that the pomegranate seeds germinated regardless of scarification, indicating the absence of physical numbness, since the seed coat did not prevent the inflow of the solution, allowing germination and the later emergence of seedlings.

The contact of the embryo with moisture before the beginning of the germination process may have damaged the emergence of pomegranate seedlings. Moreover, the solution inflow was facilitated with seed scarification due to the difference in water potential between seeds and the medium, providing an accelerated absorption of solutes and causing injuries to seeds due to the reduction of cell membranes integrity, besides the loss of nutrients considered essential to germination (Marcos Filho, 2015).
The same occurred for the mean emergence time, for which the treatments with nonscarified seeds subjected to concentrations of $\mathrm{GA}_{3}$ were significantly higher than the scarified control (18.56 day ${ }^{-1}$ ) and did not differ from the non-scarified control (22.54 day ${ }^{-1}$ ). However, for this variable, the absence of scarification and the use of $\mathrm{GA}_{3}$ for seed immersion increased the time for the occurrence of emergence (Table 1). This shows that pomegranate seeds with an intact seed coat can present higher percentages of emergence without the need for scarification and the use of gibbereIlic acid, otherwise delaying the emergence of seedlings by a few days.

For the number of leaves, the control treatment and the treatment with scarified seeds subjected to the low concentration of $\mathrm{GA}_{3}$ (500 $\mathrm{mg} \mathrm{L}^{-1}$ ) showed a significant difference from the non-treated seeds (Table 1 ). All treatments evaluated were statistically lower than the control (WT+0), which showed the highest number of leaves (10.90). As gibberellins are also synthesized in the seeds (Taiz et al., 2017), the internal content of this hormone in pomegranate seeds was probably sufficient to trigger the physiological processes of germination, emergence, and growth attributes of seedlings.

For stem diameter, all treatments with $\mathrm{GA}_{3}$ showed significantly lower values than the scarified control $(\mathrm{WH}+0)$ and the non-scarified control $(\mathrm{WT}+0)$, in which case the pomegranate seeds with an intact seed coat showed larger stem diameter than the scarified seeds, resulting in 0.62 and $0.53 \mathrm{~cm}$, respectively (Table 1 ).

In general, the shoot length of seedlings whose seeds were subjected to concentrations of $\mathrm{GA}_{3}$ was not statistically different from the scarified control treatment $(\mathrm{WH}+0)$, although 
showing significant differences compared to the non-scarified control (WT+0), with the latter being superior $(4.38 \mathrm{~cm})$ (Table 1$)$. For root length and total dry matter, the $\mathrm{WH}+500$ and $\mathrm{WH}+1,500$ treatments were statistically lower than the non-scarified control (WT+0), with $8.89 \mathrm{~cm}$ and $93.60 \mathrm{mg}$, respectively.
A significant difference can be observed in the interaction between factors for the initial emergence and for the mean emergence time (Table 2); however, the emergence percentage was only influenced by the isolated factors when performing the analysis of variance by the F-test at $5 \%$ of probability.

Table 2. Analysis of variance for initial emergence (IE), emergence percentage (EP), and mean emergence time (MET) of pomegranate seedlings (Punica granatum) produced from seeds subjected to scarification and low (500 $\left.\mathrm{mg} \mathrm{L}^{-1}\right)$, medium $\left(1,000 \mathrm{mg} \mathrm{L}^{-1}\right)$ and high concentrations $\left(1,500 \mathrm{mg} \mathrm{L}^{-1}\right)$ of $\mathrm{GA}_{3}$.

\begin{tabular}{|c|c|c|c|}
\hline \multirow{2}{*}{ Source of Variation } & IE (days) & EP (\%) & MET $\left(\right.$ days $\left.^{-1}\right)$ \\
\hline & \multicolumn{3}{|c|}{ Mean Square } \\
\hline Scarification (A) & $130.6667 *$ & $5280.6667 *$ & $268.8082^{*}$ \\
\hline Concentration (B) & $6.1250^{\mathrm{NS}}$ & $34.6667^{\mathrm{NS}}$ & $46.6059 *$ \\
\hline$A \times B$ & $22.7617 *$ & $34.6667^{\mathrm{NS}}$ & $36.5351 *$ \\
\hline C.V. (\%) & 17.29 & 21.02 & 9.92 \\
\hline Scarification & \multicolumn{3}{|c|}{ Means } \\
\hline With & $9.67 \pm 0.96 \mathrm{~B}^{1}$ & $40.33 \pm 3.17 \mathrm{~B}$ & $18.20 \pm 1.27 \mathrm{~B}$ \\
\hline Without & $14.33 \pm 0.33 \mathrm{~A}$ & $70.00 \pm 3.06 \mathrm{~A}$ & $24.90 \pm 0.51 \mathrm{~A}$ \\
\hline Concentration of $\mathrm{GA}_{3}\left(\mathrm{mg} \mathrm{L}^{-1}\right)$ & \multicolumn{3}{|c|}{ Means } \\
\hline 500 & $11.00 \pm 1.52$ & $54.50 \pm 6.59$ & $20.14 \pm 1.74$ B \\
\hline 1,000 & $12.63 \pm 0.73$ & $53.50 \pm 5.39$ & $24.34 \pm 0.84 \mathrm{~A}$ \\
\hline 1,500 & $12.38 \pm 1.30$ & $57.50 \pm 8.14$ & $20.17 \pm 1.96 \mathrm{~B}$ \\
\hline General Mean & $12.00 \pm 0.69$ & $55.17 \pm 3.77$ & $21.55 \pm 0.97$ \\
\hline
\end{tabular}

${ }^{*}$ Significant and ${ }^{\mathrm{N}}$ not significant at $5 \%$ of probability by the F-test. ${ }^{1}$ Same letters in the column (between rows) do not differ from each other by the F-test ( $5 \%$ of probability).

Source: Authors.

The percentage of emergence showed a higher value $(70 \%)$ when considering the treatments without scarification, differing statistically from those in which the pomegranate seeds were scarified (40.33\%) (Table 2 ). This shows, once again, that the seed coat of the pomegranate seeds is not a limiting factor to their immersion and germination. Monteiro et al. (2019), evaluating seedling emergence in seeds of the pomegranate $\mathrm{cv}$. 'Comum' subjected to scarification and immersion in water, concluded that these seeds present a considerable water content in their composition, and, even with an intact tegument, they still allow the solutes inflow, ensuring seedling emergence without the need for immersion in water or gibberellic acid, as performed in this study.

The absorption of solutes was probably favored when the pomegranate seeds were scarified, with consequent damage to seedling emergence. According to Dalastra et al. (2010), for some species, the contact between the embryo and the immersion solution before the beginning of germination may be harmful to this phase, since, when seeds are excessively soaked, the 
period in which the membranes have to reorganize causes an excessive release of solutes, damaging the germination process.

Furthermore, the gibberellic acid solution in which seeds were immersed may have caused phytotoxicity, as the excessive presence of $\mathrm{GA}_{3}$ induces cellular acidification (Miyamoto et al., 2012). Another assumption is that the $\mathrm{GA}_{3}$ diluted in water may have modified the osmotic potential of the solution and, as a consequence, the water potential, preventing the inflow of water into the seed and impairing seedling emergence (Takata et al., 2014).

Regarding to the percentage of emergence, there was no significant difference between the concentrations of gibberellic acid (Table 2). Corroborating with the exposed, when Takata et al. (2014) studied the effect of gibberellin in pomegranate seeds, they observed that the increase in the concentration of $\mathrm{GA}_{3}$ up to $400 \mathrm{mg} \mathrm{L}^{-1}$ did not positively influence the emergence percentage of seedlings, concluding that seed immersion in water is a more satisfactory method.

The fastest initial emergence (7 days) was registered in the treatment in which seeds were subjected to mechanical scarification and immersion in the lowest concentration of $\mathrm{GA}_{3}$ (Table 3). Although the highest emergence percentage was observed in the seedlings produced from non-scarified seeds (Table 2), the initial emergence in these conditions was late compared to the treatment in which the seeds were scarified, demonstrating a greater difference, especially among seeds immersed on the medium and highest concentration of gibberellic acid (Table 3 ). The same behavior was verified by Osipi et al. (2018) when associating pomegranate seeds without scarification with immersion in $\mathrm{GA}_{3}$, observing a delay in the initial emergence of seedlings compared to the remaining treatments.

Table 3. Initial emergence (IE) and mean emergence time (MET) of pomegranate seedlings

(Punica granatum) produced from seeds subjected to scarification and low $\left(500 \mathrm{mg} \mathrm{L}^{-1}\right)$, medium $\left(1,000 \mathrm{mg} \mathrm{L}^{-1}\right)$, and high concentrations $\left(1,500 \mathrm{mg} \mathrm{L}^{-1}\right)$ of $\mathrm{GA}_{3}$.

\begin{tabular}{|c|c|c|}
\hline \multirow{3}{*}{$\begin{array}{l}\text { Concentration of } \mathrm{GA}_{3} \\
\left(\mathrm{mg} \mathrm{L}^{-1}\right)\end{array}$} & \multicolumn{2}{|c|}{ IE (days) } \\
\hline & \multicolumn{2}{|c|}{ Scarification } \\
\hline & WITH* & WITHOUTNS \\
\hline $500 *$ & $7.00 \pm 0.00 \mathrm{~B}^{1} \mathrm{~b}^{2}$ & $15.00 \pm 0.41 \mathrm{Aa}$ \\
\hline $1,000^{\mathrm{NS}}$ & $12.00 \pm 1.47 \mathrm{Aa}$ & $13.25 \pm 0.25 \mathrm{Aa}$ \\
\hline $1,500 *$ & $10.00 \pm 1.92 \mathrm{Ab}$ & $14.75 \pm 0.63 \mathrm{Aa}$ \\
\hline \multirow{3}{*}{$\begin{array}{l}\text { Concentration of } \mathbf{G A}_{3} \\
\left(\mathrm{mg} \mathrm{L}^{-1}\right)\end{array}$} & \multicolumn{2}{|c|}{ MET (days $\left.{ }^{-1}\right)$} \\
\hline & \multicolumn{2}{|c|}{ Scarification } \\
\hline & WITH* & WITHOUTNS \\
\hline $500 *$ & $15.78 \pm 0.75 \mathrm{Bb}$ & $24.50 \pm 0.95 \mathrm{Aa}$ \\
\hline $1,000^{\mathrm{NS}}$ & $23.45 \pm 1.58 \mathrm{Aa}$ & $25.23 \pm 0.50 \mathrm{Aa}$ \\
\hline $1,500 *$ & $15.39 \pm 0.99 \mathrm{Bb}$ & $24.96 \pm 1.29 \mathrm{Aa}$ \\
\hline
\end{tabular}

*Significant and ${ }^{\mathrm{N}}$ not significant at $5 \%$ of probability by the F-test. ${ }^{1}$ Same uppercase letters in the column (between rows) do not differ from each other by Tukey's test at $5 \%$ of probability; ${ }^{2}$ Same lowercase letters in the row (between columns) do not differ from each other by the F-test at $5 \%$ of probability.

Source: Authors. 
Lower initial emergence values are considered adequate since the rate and uniformity of seed germination and seedling emergence are essential aspects of good seedling formation. The longer the seedling remains in the early stages of development, delaying emergence, the more susceptible it will be to adverse environmental conditions.

The initial emergence and mean emergence time followed the same pattern since, for the second variable, the lowest values were also observed when the pomegranate seeds were scarified and subjected to low (15.78 days ${ }^{-1}$ ) and high (15.39 days $^{-1}$ ) concentrations of $\mathrm{GA}_{3}$, differing from the remaining treatments ( $\mathrm{Ta}$ ble 3). Although the association of seed scarification and immersion in $\mathrm{GA}_{3}$ was unfavorable to increase the emergence percentage of pomegranate $\mathrm{cv}$. Valenciana, the combination of scarification and immersion of the seeds in $500 \mathrm{mg} \mathrm{L}^{-1} \mathrm{GA}_{3}$ reduced the initial emergence and the time to obtain the seedlings (Tables 1 and 3 ). This may indicate that this cultivar is promising for the production of pomegranate rootstocks since the rapid plant development implies shorter permanence in the plant nursery, providing to the producer several benefits such as lower costs and the more efficient use of this facility.

According to the analysis of variance, the growth variables stem diameter, shoot length and root length of the pomegranate seedlings evaluated in this study, presented a significant difference by the F-test ( $5 \%$ probability) for the interaction between the evaluated factors, as observed in Table 4.

Table 4. Analysis of variance for the number of leaves (NL), stem diameter (SD) (mm), shoot length $(\mathrm{SL})(\mathrm{cm})$, root length $(\mathrm{RL})(\mathrm{cm})$, and total dry matter $(\mathrm{TDM})(\mathrm{mg})$ of pomegranate seedlings

(Punica granatum) produced from seeds subjected to scarification and low (500 $\mathrm{mg} \mathrm{L}^{-1}$ ), medium $\left(1,000 \mathrm{mg} \mathrm{L}^{-1}\right)$, and high concentrations $\left(1,500 \mathrm{mg} \mathrm{L}^{-1}\right)$ of $\mathrm{GA}_{3}$.

\begin{tabular}{|c|c|c|c|c|c|}
\hline \multirow{2}{*}{$\begin{array}{l}\text { Sources of } \\
\text { variation }\end{array}$} & NL & SD & SL & $\mathbf{R L}$ & TDM \\
\hline & \multicolumn{5}{|c|}{ Mean Square } \\
\hline Scarification (A) & $12.0333 *$ & $0.0521 *$ & $0.0919^{N S}$ & $81.4112 *$ & $0.0035^{*}$ \\
\hline Concentration (B) & $1.7333^{\mathrm{NS}}$ & $0.0018^{\mathrm{NS}}$ & $2.6728^{*}$ & $20.1380 *$ & $0.0001^{\mathrm{NS}}$ \\
\hline$A \times B$ & $6.0333^{*}$ & $0.1287 *$ & $1.2271^{*}$ & $44.2892 *$ & $0.0006^{*}$ \\
\hline C.V. (\%) & 23.52 & 30.07 & 17.56 & 30.39 & 18.41 \\
\hline \multicolumn{3}{|l|}{ Scarification } & \multicolumn{2}{|l|}{ Means } & \\
\hline With & $6.92 \pm 0.26 \mathrm{~B}^{1}$ & $0.21 \pm 0.01 \mathrm{~B}$ & $3.50 \pm 0.12$ & $7.15 \pm 0.37 \mathrm{~B}$ & $71.17 \pm 29.24 B$ \\
\hline Without & $7.55 \pm 0.17 \mathrm{~A}$ & $0.26 \pm 0.01 \mathrm{~A}$ & $3.45 \pm 0.05$ & $8.80 \pm 0.29 \mathrm{~A}$ & $86.35 \pm 18.57 \mathrm{~A}$ \\
\hline \multicolumn{3}{|l|}{$\begin{array}{l}\text { Concentration } \\
\text { of } \mathbf{G A}_{3}\left(\mathbf{m g ~ L}^{-1}\right)\end{array}$} & \multicolumn{2}{|l|}{ Means } & \\
\hline 500 & $7.30 \pm 0.31$ & $0.23 \pm 0.02$ & $3.28 \pm 0.08 \mathrm{~B}$ & $8.45 \pm 0.52 \mathrm{~A}$ & $76.58 \pm 35.90$ \\
\hline 1,000 & $7.00 \pm 0.19$ & $0.24 \pm 0.01$ & $3.38 \pm 0.07 \mathrm{~B}$ & $8.31 \pm 0.37 \mathrm{~A}$ & $81.63 \pm 31.81$ \\
\hline 1,500 & $7.40 \pm 0.31$ & $0.24 \pm 0.01$ & $3.71 \pm 0.13 \mathrm{~A}$ & $7.16 \pm 0.37 \mathrm{~B}$ & $78.09 \pm 43.68$ \\
\hline General mean & $7.23 \pm 0.16$ & $0.24 \pm 0.01$ & $3.47 \pm 0.06$ & $7.97 \pm 0.25$ & $78.76 \pm 2.14$ \\
\hline
\end{tabular}

*Significant and ${ }^{N S}$ not significant at $5 \%$ of probability by the F-test. ${ }^{1}$ Same letters in the column (between rows) do not differ from each other by the F-test ( $5 \%$ of probability). 
The highest number of leaves (8.05 leaves) was observed in the pomegranate seedlings produced from seeds without scarification and soaked in a low concentration of gibberellic acid
(500 $\mathrm{mg} \mathrm{L}^{-1}$ ), only differing from the treatment in which the seeds were scarified and subjected to the same concentration of $\mathrm{GA}_{3}(6.55$ leaves) (Table 5).

Table 5. Number of leaves (NL), stem diameter (SD), shoot length (SL), root length (RL), and total dry matter (TDM) of pomegranate seedlings (Punica granatum) produced from seeds subjected scarification and low (500 $\left.\mathrm{mg} \mathrm{L}^{-1}\right)$, medium $\left(1,000 \mathrm{mg} \mathrm{L}^{-1}\right)$ and high concentrations $\left(1,500 \mathrm{mg} \mathrm{L}^{-1}\right)$ of $\mathrm{GA}_{3}$.

\begin{tabular}{|c|c|c|}
\hline \multirow{3}{*}{$\begin{array}{l}\text { Concentration of } \mathrm{GA}_{3} \\
\left(\mathrm{mg} \mathrm{L}^{-1}\right)\end{array}$} & \multicolumn{2}{|c|}{ NL } \\
\hline & \multicolumn{2}{|c|}{ Scarification } \\
\hline & WITHNS & WITHOUTNS \\
\hline $500 *$ & $6.55 \pm 0.43 \mathrm{~A}^{1} \mathrm{~b}^{2}$ & $8.05 \pm 0.37 \mathrm{Aa}$ \\
\hline $1,000^{\mathrm{NS}}$ & $6.80 \pm 0.32 \mathrm{Aa}$ & $7.20 \pm 0.21 \mathrm{Aa}$ \\
\hline $1,500^{\mathrm{NS}}$ & $7.40 \pm 0.58 \mathrm{Aa}$ & $7.40 \pm 0.26 \mathrm{Aa}$ \\
\hline \multirow{3}{*}{$\begin{array}{l}\text { Concentration of } \mathbf{G A}_{3} \\
\left(\mathrm{mg} \mathrm{L}^{-1}\right)\end{array}$} & \multicolumn{2}{|c|}{ SD (mm) } \\
\hline & \multicolumn{2}{|c|}{ Scarification } \\
\hline & WITH* & WITHOUT* \\
\hline $500 *$ & $0.14 \pm 0.01 \mathrm{Bb}$ & $0.31 \pm 0.01 \mathrm{Aa}$ \\
\hline $1,000 *$ & $0.26 \pm 0.02 \mathrm{Aa}$ & $0.21 \pm 0.01 \mathrm{Bb}$ \\
\hline $1,500^{\mathrm{NS}}$ & $0.24 \pm 0.02 \mathrm{Aa}$ & $0.24 \pm 0.02 \mathrm{Ba}$ \\
\hline \multirow{3}{*}{$\begin{array}{l}\text { Concentration of } \mathrm{GA}_{3} \\
\left(\mathrm{mg} \mathrm{L}^{-1}\right)\end{array}$} & \multicolumn{2}{|c|}{ SL (cm) } \\
\hline & \multicolumn{2}{|c|}{ Scarification } \\
\hline & WITH* & WITHOUT ${ }^{\mathrm{NS}}$ \\
\hline $500^{\mathrm{NS}}$ & $3.13 \pm 0.12 \mathrm{Ba}$ & $3.43 \pm 0.11 \mathrm{Aa}$ \\
\hline $1,000^{\mathrm{NS}}$ & $3.41 \pm 0.12 \mathrm{Ba}$ & $3.35 \pm 0.06 \mathrm{Aa}$ \\
\hline $1,500 *$ & $3.97 \pm 0.25 \mathrm{Aa}$ & $3.57 \pm 0.08 \mathrm{Ab}$ \\
\hline \multirow{3}{*}{$\begin{array}{l}\text { Concentration of } \mathrm{GA}_{3} \\
\left(\mathrm{mg} \mathrm{L}^{-1}\right)\end{array}$} & \multicolumn{2}{|c|}{$R L(c m)$} \\
\hline & \multicolumn{2}{|c|}{ Scarification } \\
\hline & WITH* & WITHOUT* \\
\hline $500 *$ & $6.42 \pm 0.60 \mathrm{Ab}$ & $10.49 \pm 0.54 \mathrm{Aa}$ \\
\hline $1,000^{\mathrm{NS}}$ & $8.14 \pm 0.57 \mathrm{Aa}$ & $8.48 \pm 0.48 \mathrm{Ba}$ \\
\hline $1,500^{\mathrm{NS}}$ & $6,90 \pm 0.73 \mathrm{Aa}$ & $7.42 \pm 0.17 \mathrm{Ba}$ \\
\hline \multirow{3}{*}{$\begin{array}{l}\text { Concentration of } \mathbf{G A}_{3} \\
\left(\mathrm{mg} \mathrm{L}^{-1}\right)\end{array}$} & \multicolumn{2}{|c|}{ TDM (mg) } \\
\hline & \multicolumn{2}{|c|}{ Scarification } \\
\hline & WITH* & WITHOUTNS \\
\hline $500 *$ & $62.73 \pm 2.13 \mathrm{Ab}$ & $90.42 \pm 2.70 \mathrm{Aa}$ \\
\hline $1,000^{\mathrm{NS}}$ & $77.12 \pm 5.17 \mathrm{Aa}$ & $86.13 \pm 3.39 \mathrm{Aa}$ \\
\hline $1,500^{\mathrm{NS}}$ & $73.66 \pm 8.07 \mathrm{Aa}$ & $82.51 \pm 3.33 \mathrm{Aa}$ \\
\hline
\end{tabular}

*Significant and ${ }^{\mathrm{NS}}$ not significant at $5 \%$ of probability by the F-test. ${ }^{1}$ Same uppercase letters in the column (between rows) do not differ from each other by Tukey's test at 5\% of probability; ${ }^{2}$ Same lowercase letters in the row (between columns) do not differ from each other by the F-test at $5 \%$ of probability. 
Although the scarification facilitated the solution inflow into the seeds, it was insufficient to provide a higher number of leaves in the pomegranate seedlings, probably due to the exclusive use of gibberellic acid in this study. A distinct response could have been observed if cytokinin was present in the immersion solution since this plant growth regulator induces the transportation of nutrients from other parts of the plant to the leaves, allowing the development of chloroplasts and the increase in photosynthesis (Taiz et al., 2017).

The stem diameter of pomegranate seedlings was larger $(0.31 \mathrm{~mm})$ when there was no seed scarification associated with the lowest concentration of gibberellic acid, presenting a superior and significantly different mean from the remaining treatments (Table 5). Likewise, in a study performed by Monteiro et al. (2019), seeds of pomegranate cv. Comum with intact seed coat resulted in seedlings with larger stem diameters, compared to scarified seeds.

It was observed that, with the increasing concentrations of $\mathrm{GA}_{3}$ in the immersion of scarified seeds, there was a similarity between increases in the number of leaves and in the stem diameter of pomegranate seedlings. This occurred due to the exchange activities that occur in the seedlings during the growth in diameter, driven by photosynthetic actions and by the translocation of hormones from the apical regions (Larcher, 2006).

A longer shoot length $(3.97 \mathrm{~cm})$ was verified when the pomegranate seeds were scarified and soaked in the highest concentration of $\mathrm{GA}_{3}$, differing from the remaining treatments (Table 5). This result is in agreement with Taiz et al. (2017), when they affirmed that the growth in height is promoted by the stimulus that gibberellin causes on cell division and elongation. There was no difference between the concentrations of gibberellic acid in the seedlings that originated from non-scarified seeds (Table 5 ).

While the scarified pomegranate seeds did not differ in root length values in $\mathrm{GA}_{3}$ concentrations, the seeds with an intact seed coat reduced the results of this variable, and the lowest concentration of gibberellic acid resulted in a root length of $10.49 \mathrm{~cm}$, differing from the remaining treatments (Table 5). These results indicate that, such as reported by Taiz et al. (2017), gibberellin does not act expressively by influencing root growth compared to other bioregulators, such as auxin and abscisic acid.

The accumulation of total dry matter was higher in pomegranate seedlings produced from non-scarified seeds, when these were subjected to the lowest concentration of gibberellic acid (90.42 $\mathrm{mg})$, only differing from the treatment in which the seeds were scarified (62.73 mg) (Table 5).

This probably occurred due to the higher values observed for the non-scarified seeds regarding to the number of leaves, stem diameter, and root system length. According to Choudhary \& Chakrawar (1982), these results may have led to the general assimilation and redistribution of photosynthates within the plant, resulting in greater dry mass and increasing the incorporation of total dry matter.

Such responses indicate that the pressure through a sieve, under running water, is an efficient method to remove the sarcotesta of pomegranate seeds and, associated to that, the lowest concentration of $\mathrm{GA}_{3}$ used in this study was sufficiently effective in incrementing the biometric variables, which are essential for seedling growth. 
As a recommendation for future studies, it is suggested to evaluate different immersion times in gibberellic acid and different substrates for growing pomegranate rootstocks.

\section{CONCLUSIONS}

The seeds of the pomegranate cv. Valenciana do not have tegument-related dormancy.

In order to favor the emergence percentage and the initial growth of pomegranate seedlings, mechanical scarification and immersion of seeds in gibberellic acid are dispensed.

Scarification and immersion of pomegranate seeds in $500 \mathrm{mg} \mathrm{L}^{-1}$ of $\mathrm{GA}_{3}$ are recommended to produce seedlings a shorter time.

\section{AUTHOR'S CONTRIBUTION}

First author: Methodology, research, data analysis, conceptualization, writing, original draft. Second author: Research, conceptualization, data analysis, writing, review and editing. Third author: Data analysis, review and editing. Fourth author: Logistics, review and edition. Fifth author: Resource acquisition, project manager, supervision, conceptualization.

\section{ACKNOWLEDGEMENTS}

The authors would like to thank the Coordination for the Improvement of Higher Education Personnel (CAPES) for the financial support.

\section{CITED LITERATURE}

Aguilera-Arango, G.A., Lombo-Ortiz, D.F., BurbanoErazo, E. \& Orduz-Rodriguez, J.O. (2020). Granado (Punica granatum L.), un cultivo con potencial productivo: revisión y situación en Colombia. Tropical and Subtropical Agroecosystems, 23 (1), 1-15. https://www.revista.ccba.uady.mx/ojs/ index.php/TSA/article/view/3065/1385
Asadi, M.S., Mirghazanfari, S.M., Dadpay, M. \& Nassireslami, E. (2018). Evaluation of wound healing activities of pomegranate (Punica granatum - Lythraceae) peel and pulp. Journal of Research in Medical and Dental Science, 6 (3), 230236. https://doi.org/10.24896/jrmds.20186336

Batista, P.F., Maia, S.S.S., Coelho, M.F.B., Benedito, C.P. \& Guimarães, I.P. (2011). Propagação vegetativa de romã em diferentes substratos. Revista Verde de Agroecologia e Desenvolvimento Sustentável, 6 (4), 96-100. https://www. gvaa.com.br/revista/index.php/RVADS/article/ view/1053/884

Bensaad, L.A., Kim, K.H., Quah, C.C., Kim, W.R. \& Shahimi, M. (2017). Anti-inflammatory potential of ellagic acid, gallic acid and punicalagin $A \& B$ isolated from Punica granatum. BMC Complementary and Alternative Medicine, 17 (1), 1-10. https://doi.org/10.1186/s12906-017-1555-0

Choudhary, B.K. \& Chakrawar, V.K. (1982). Note on the effect of some chemicals on the germination of Rangpur Lime seeds. Indian Journal of Agricultural Science, 51 (3), 201-203.

Dalastra, I.M., Pio, R., Entelmann, F.A., Werle, T., Uliana, M.B. \& Scarpare Filho, J.A. (2010). Germinação de sementes de nogueira-macadâmia submetidas à incisão e imersão em ácido giberélico. Ciência e Agrotecnologia, 34 (3), 641-645. https://doi.org/10.1590/S141370542010000300016

Ferreira, D.F. (2019). Sisvar: a computer analysis system to fixed effects split plot type designs. Revista Brasileira de Biometria, 37 (4), 529-535. https://doi.org/10.28951/rbb.v37i4.450

Khadivi-Khub, A., Kameli, M., Moshfeghi, N. \& Ebrahi$\mathrm{mi}, \mathrm{A}$. (2015). Phenotypic characterization and relatedness among some Iranian pomegranate (Punica granatum L.) accessions. Trees, 29 (3), 893-901. https://doi.org/10.1007/s00468-015-1172-9

Labouriau, L.G. (1983). A germinação das sementes. Washington: Secretaria Geral da Organização dos Estados Americanos.

Larcher, W. (2006). Ecofisiologia vegetal. São Carlos: RIMA Artes e Textos. 
Marcos Filho, J. (2015). Fisiologia de sementes de plantas cultivadas. Londrina: ABRATES.

Materechera, A.S. \& Seeiso, T.M. (2013). Seed treatment to improve water imbibition and germination of pomegranate (Punica granatum). Acta Horticulturae, 979, 713-721. https://doi. org/10.17660/ActaHortic.2013.979.80

Melo, A.P.C. \& Seleguini, A. (2013). Estádio de maturação de frutos e remoção física da sarcotesta na produção de mudas de mamão. Comunicata Scientiae, 4 (1), 20-25. http://repositorio.bc.ufg. $\mathrm{br} /$ tede/handle/ri/13902

Miyamoto, T., DeRose, R., Suarez, A., Ueno, T., Chen, M., Sun, T., Wolfgang, M.J., Mukherjee, C., Meyers, D.J. \& Inoue, T. (2012). Rapid and orthogonal logic gating with a gibberellin-induced dimerization system. Nature Chemical Biologic, 8 (5), 465-470. https://doi.org/10.1038/nchembio.922

Monteiro, L.N.H., Boliani, A.C., Ferreira, A.F.A., Rodrigues, M.G.F., Faria, G.A., Silva, M.S.C., Oliveira, M.P., Cunha, S.R. \& Ribeiro, L.R. (2019). Implication of some pre-germination treatments on seeds and initial seedling growth of pomegranate (Punica granatum L.). Australian Journal of Crop Science, 13 (4), 558-565. https://doi. org/10.21475/ajcs.19.13.04.p1496

Osipi, E.A.F., Carvalho, D.U., Cruz, M.A., Osipe, J.B., Cossa, C.A. \& Sorace, M.A. (2018). Sarcotesta removal methods and $\mathrm{GA}_{3}$ treatment on germination of Punica granatum L. seeds. Biotemas, 31 (2), 1-8. https://doi.org/10.5007/21757925.2018v31n2p1
Peixoto, E.C.T.M., Moreira, G.M.B., Figueiredo, A., Matsumoto, L.S., Silva, R.M.G. \& Domingues, P.F. (2014). Extrato aquoso de Punica granatum Linn. no tratamento de mastite bovina subclínica. Cadernos de Agroecologia, 9 (1), 1-5. http:// revistas.aba-agroecologia.org.br/index.php/cad/ article/view/15497/10059

Takata, W., Silva, E.G., Corsato, J.M. \& Ferreira, G. (2014). Germinação de sementes de romãzeiras (Punica granatum L.) de acordo com a concentração de giberelina. Revista Brasileira de Fruticultura, 36 (1), 254-260. http://dx.doi. org/10.1590/0100-2945-269/13

Taiz, L., Zeiger, E., Moller, I. A. \& Murphy A. (2017). Fisiologia e desenvolvimento vegetal. Porto Alegre: Artmed.

ValizadehKaji, B., Abbasifar, A., Bagheri, H., Zandievakili, G. \& Daryabeigi, A. (2020). First report: grafting of three Iranian commercial pomegranate cultivars on drought tolerant rootstocks. International Journal of Horticultural Science and Technology, 7 (1), 69-79. https://doi. org/10.22059/IJHST.2020.284659.304

Vasconcelos, L.H.C., Vendruscolo, E.P., Vasconcelos, R.F., Santos, M.M. \& Seleguini, A. (2015). Utilização de métodos físicos e de fitorreguladores para superação de dormência em sementes de pinha. Journal of Neotropical Agriculture, 2 (4), 20-24. https://periodicosonline.uems.br/index.php/agrineo/article/view/267
Conflicto de Intereses Los autores declaran no tener ningún conflicto de intereses

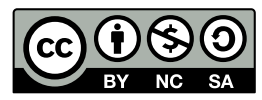


